\title{
Oncological Prognosis and Fertility Outcomes of Different Surgical Extents for Malignant Ovarian Sex-Cord Stromal Tumors: A Narrative Review
}

\author{
Jiawei Li D, Jun Li, Wei Jiang \\ Department of Gynecologic Oncology, Obstetrics and Gynecology Hospital, Fudan University, Shanghai, People's Republic of China
}

Correspondence: Wei Jiang, Department of Gynecologic Oncology, Obstetrics and Gynecology Hospital, Fudan University, No. 4I9, Fangxie Road, Shanghai, 2000II, People's Republic of China, Tel +86 13916922627, Email jw523I7@I26.com

Background: Malignant ovarian sex-cord stromal tumors (MOSCSTs) are rare neoplasms that account for approximately 5-7\% of all ovarian malignancies. The majority (70\%) of patients had an early stage; thus, surgery is the predominant treatment. Patients were relatively young at the onset of the tumor. Moreover, the prognosis of patients with this tumor is better than that of malignant epithelial ovarian tumors and tends to recur late with an indolent clinical course. Thus, patients may be more inclined to conservative surgical procedures. There is, however, no objective criterion for selecting a suitable surgical procedure. Clinically, surgical extent depended on the preoperative evaluations, age, and willingness of patients, and gynecologists were relatively subjective when choosing surgery. The prognosis of patients with different surgical extents is still controversial. The review aimed to summarize the impacts of different surgical extents on oncological prognosis and fertility outcomes.

Methods: The literature search was performed in PubMed (https://www.ncbi.nlm.nih.gov/pubmed/), and publications between January 2011 and December 2021 in English including clinical cohort studies and case reports were eligible for inclusion.

Results: We finally identified 12 large-sample retrospective studies and 18 cases of MOSCSTs. The primary surgical procedures include fertility-spring surgery (FSS), total hysterectomy with unilateral or bilateral salpingo-oophorectomy (TAH-USO/BSO), FSS with complete staging procedure, complete staging surgery (CSS), and debulking surgery. FSS includes cystectomy (CYS), unilateral salpingo-oophorectomy (USO) or bilateral salpingo-oophorectomy (BSO) with uterine preservation that allows for potential future assisted reproductive approaches. Complete staging procedure includes peritoneal cytologic examinations, inspections of peritoneal surfaces, random peritoneal biopsies and omentectomy. FSS with complete staging procedure means surgical procedure with uterine preservation and complete staging procedure. And, generally, CSS means TAH-BSO with complete staging procedure.

Conclusion: It can be concluded that USO can be done in young, fertility-desired patients with tumors confined to the ovary but avoid CYS. FSS with complete staging procedure is feasible among stage IC-III patients who have fertility desire. Patients can choose to have a complete surgery once their family is complete or without fertility requirements. CSS is recommended for patients with risk factors such as high stage, poor differentiation, and large tumor size and without fertility desire. A close follow-up is essential.

Keywords: malignant sex-cord stromal tumor, surgical extent, risk factors, prognosis, fertility outcomes

\section{Introduction}

MOSCSTs represents $2-5 \%$ of all malignant ovarian tumors. Other rare subtypes include Sertoli-Leydig cell tumor (SLCT) (5-10\%), Sertoli cell carcinoma, Leydig cell tumor, sex cord tumor with annular tubules (1.4\%) and so on ${ }^{1}$ whereas GCT is the most common subtype (70\%). MSCSTs are usually diagnosed at an early stage in patients of childbearing age. ${ }^{2}$ This tumor is characterized by a relatively good prognosis and late recurrence. The median time to recurrence is six years, as late as 30 years. $^{2}$ Fifty-four percent of the patients with GCT recurrences occurred within 5 years; patients recurring from 5 to 10 years after diagnosis accounted for $39 \%$; $6 \%$ of the patients experienced recurrence after more than 20 years from initial diagnosis. ${ }^{3}$ 
According to NCCN guidelines, surgery for women who desire fertility and whose tumor is grossly confined to the ovary usually consists of a USO or BSO with complete staging. All others should undergo complete staging, which means TAH-BSO with complete staging. However, evidence regarding the impact of different surgical procedures on the outcomes of MOSCST patients is limited. Moreover, a large surgical extent may be associated with long-term side effects that affect sexual function and quality of life. Patients may be more inclined to conservative surgical procedures due to the relatively good prognosis and indolent clinical course of this tumor. Determining surgical extent is mainly based on accurate preoperative staging. However, it cannot be done because the stage was determined by surgical pathology. The decision to perform conservative surgery rather than a more extensive procedure is often made intraoperatively by the surgeon based on the surgeon's experience, intraoperative findings, and fresh frozen intraoperative analysis. ${ }^{4-7}$ However, fresh frozen intraoperative analysis still has certain limitations. The sensitivity and specificity of fresh frozen intraoperative analysis for MOSCSTs were $95.5 \%$ and $93.8 \%$, respectively. ${ }^{8}$ The accuracy rate of the frozen pathological evaluation was only $60 \%$ for Sertoli-Leydig cell tumor. ${ }^{9}$ Thus, there is no objective criterion when deciding surgical procedures.

Whether different surgical extents affect survival and fertility outcome remain controversial. We undertook a narrative review to summarize the oncologic and fertility outcomes of different extents of surgery among MOSCST patients. The literature search was performed in PubMed (https://www.ncbi.nlm.nih.gov/pubmed/). A summary of recent studies on the impact of different surgical procedures on prognosis is shown in Table 1. A summary of recent case reports of MSCSTs is shown in Table $2 .^{10-21}$

\section{Oncological Prognosis: Impact of Different Surgical Procedures and Routes Fertility-Spring Surgery (FSS) vs TAH-BSO}

Because of the lower age of onset coupled with the increasing childbearing age, the number of patients with MSCST planning pregnancy has accelerated, and cancer diagnosed during pregnancy is likely to upsurge. ${ }^{22}$ FSS is an appropriate option, although the prognosis is still debatable Many studies compared the safety and prognosis of FSS compared to TAH-BSO.

Some studies said that patients who underwent FSS had a poor prognosis. A study based on American National Cancer Database (NCDB) published in 2017 showed that women who underwent USO had decreased survival compared with TAH-BSO, even in patients with stage I (5-y overall survival (OS) $90.2 \%$ vs $48.2 \%, \mathrm{P}=0.002$ in all patients; 5 -y OS in stage I patients $92.6 \%$ vs $87.7 \%, \mathrm{P}<0.001) .{ }^{5}$ However, the majority of deaths in this cohort were experienced by women who were no longer of reproductive age. Thus, these results cannot deny the value of FSS inappropriately counseled and well-selected young patients. A SEER-based study in 2017 drew a similar conclusion that premenopausal patients with stage I MOSCSTs who underwent FSS had poorer 20-y cancer-specific survival (CSS) than those who underwent TAH-BSO (94.2\% vs $71.7 \%, \mathrm{P}=0.021$. In this study, FSS was more common in women with non-GCT and stage IC disease versus stage IA. After controlling for tumor histology (GCT or non-GCT) and stage (stage IA or stage IC), FSS was still connected to poorer 20-y cancer-specific survival. However, there was no difference in 5-y cancerspecific survival, 10-y cancer-specific survival, and OS between the two groups. This difference may partly be clarified because women who had TAH-BSO were older and more likely to die from other causes. ${ }^{23}$ However, no further stratification by age and complications was performed in this study, and this finding remains to be further verified. A study published in 2019 analyzed patients with stage I adult granulosa cell tumor (AGCT) treated at the MITO center and showed that patients who underwent FS had worse 10-y DFS compared with patients who underwent RS (10-y disease-free survival (DFS) $50 \%$ vs $74 \%, \mathrm{P}=0.006$ ), while no difference in OS was detected. ${ }^{4}$ In this study, FSS was characterized as CYS and USO, while RS was specified as BSO and TAH-BSO. Patients who underwent CYS-only also showed a significantly worse 10 -y DFS than RS $(16 \%$ vs $75 \%, \mathrm{P}<0.001)$. However, there was no significant difference of 10 -y DFS between USO and RS (10-y DFS $70 \%$ vs $75 \%, \mathrm{p}=0.5) .{ }^{4}$ When comparing the prognosis of different FSS, patients who underwent CYS-only and USO had significant differences in DFS $(28.2 \%$ vs $85.7 \%, \mathrm{P}=0.01){ }^{4}$ Patients who had USO followed by CYS had a better prognosis than those who underwent CYS only, but prognosis was worse than the initial USO. ${ }^{4}$ That could be explained by the postoperative residual disease after CYS that appeared in some cases. ${ }^{24}$ 
Table I Summary of Recent Studies on the Impact of Different Surgical Procedures on Prognosis

\begin{tabular}{|c|c|c|c|c|c|c|c|c|}
\hline Year & First Author & $\begin{array}{l}\text { Tumor } \\
\text { Type }\end{array}$ & No. of Patients & Stage & $\begin{array}{l}\text { Surgery (No. of } \\
\text { Patients) }\end{array}$ & $\begin{array}{l}\text { Follow-Up } \\
\text { Time }\end{array}$ & Prognosis & Risk Factors \\
\hline 2020 & C. Lenck ${ }^{46}$ & GCT & 414 & I-IV & $\begin{array}{l}\text { CSS vs PCS vs } \\
\mathrm{NCS}^{\mathrm{a}}\end{array}$ & $\begin{array}{l}168 \text { months } \\
\text { (at least } 54 \\
\text { months) }\end{array}$ & $\begin{array}{l}\text { The analysis of survival did not } \\
\text { demonstrate a significant difference in } \\
\text { overall survival nor in PFS in the fully } \\
\text { compliant group compared to other } \\
\text { groups. }\end{array}$ & I \\
\hline 2019 & A. Bergamini ${ }^{4}$ & AGCT & 229 & I & $\begin{array}{l}\text { FSS (78) (USO (49), } \\
\text { CYS (I3), CYS- } \\
\text { USO (I6)) vs RS } \\
(161)^{\text {b }}\end{array}$ & $\begin{array}{l}84 \text { months } \\
\text { (range: } 35- \\
110 \text { months) }\end{array}$ & 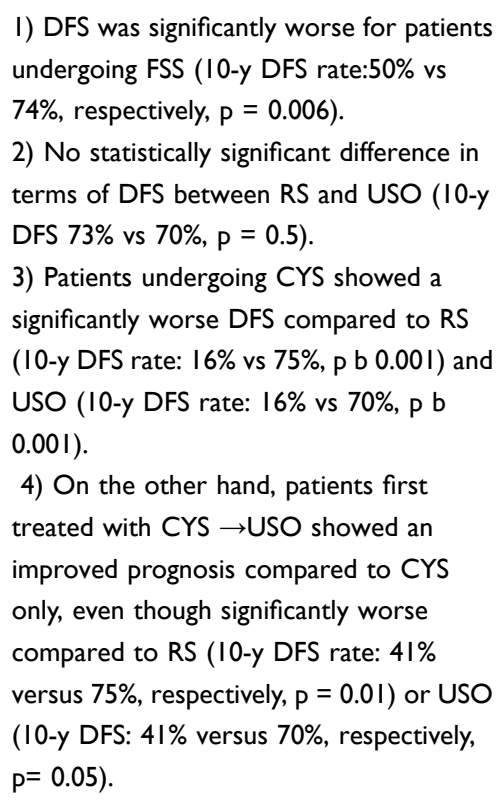 & $\begin{array}{l}\text { Age more than } 50 \text { years, } \\
\text { Stage IC, Incomplete staging. }\end{array}$ \\
\hline 2019 & Yasin Durmu ${ }^{9}$ & SLCT & 17 & I & $\begin{array}{l}\text { TAH-BSO }{ }^{c}(8) \text { vs } \\
\text { USO/O (7) vs CYS } \\
\text { (2) }\end{array}$ & 78 months & $\begin{array}{l}\text { All the } 17 \text { patients were alive and free of } \\
\text { disease for I- } 287 \text { months after the } \\
\text { diagnosis. }\end{array}$ & l \\
\hline 2018 & Dan Wang ${ }^{7}$ & AGCT & 113 & I & $\operatorname{FSS}(61)$ vs RS(52) & $\begin{array}{l}99.2 \text { months } \\
\text { (range: } 20.2- \\
394.3 \\
\text { months) }\end{array}$ & $\begin{array}{l}\text { No difference in disease-free survival } \\
\text { between the groups who underwent FSS } \\
\text { or radical surgery }(P=0.550) \text {. The } \\
\text { pregnancy rate was } 86.4 \% \text { and the live } \\
\text { birth rate was } 95 \% \text {. }\end{array}$ & $\begin{array}{l}\text { Treatment site, FIGO stage, } \\
\text { surgical, completeness of } \\
\text { staging surgery. }\end{array}$ \\
\hline
\end{tabular}


Table I (Continued).

\begin{tabular}{|c|c|c|c|c|c|c|c|c|}
\hline Year & First Author & $\begin{array}{l}\text { Tumor } \\
\text { Type }\end{array}$ & No. of Patients & Stage & $\begin{array}{l}\text { Surgery (No. of } \\
\text { Patients) }\end{array}$ & $\begin{array}{l}\text { Follow-Up } \\
\text { Time }\end{array}$ & Prognosis & Risk Factors \\
\hline 2019 & $\begin{array}{l}\text { SEBASTIEN } \\
\text { GOUY }^{34}\end{array}$ & SLCT & 23 & $\begin{array}{l}I A(n=I 5), I B \mid(n \\
=I), I C I(n=5) \text {, IIB } \\
(n=I) \text {, and IIIC (n } \\
=I)\end{array}$ & FSS vs $\mathrm{RS}^{\mathrm{e}}$ & $\begin{array}{l}17-252 \\
\text { month }\end{array}$ & $\begin{array}{l}\text { We observed eight relapses (stage la, } n= \\
2 ; \mathrm{lb}, \mathrm{n}=\mathrm{I} ; \mathrm{IcI}, \mathrm{n}=3 ; \mathrm{llb}, \mathrm{n}=\mathrm{I} ; \mathrm{IIlc}, \mathrm{n}=\mathrm{I} \text { ). } \\
\text { Recurrent disease was found in five and } \\
\text { three patients from the conservative } \\
\text { surgery and radical surgery groups, } \\
\text { respectively. }\end{array}$ & $\begin{array}{l}\text { Stage, tumor differentiation, } \\
\text { presence of heterologous } \\
\text { elements, presence of } \\
\text { a retiform pattern. }\end{array}$ \\
\hline 2017 & $\begin{array}{l}\text { Dimitrios } \\
\text { Nasioudis }^{23}\end{array}$ & MSCSTs & 255 & $\begin{array}{l}I A(n=195,76.5 \%) \\
I C(n=43.17 \%) ; I B \\
(I)\end{array}$ & $\begin{array}{l}\text { FSS }(161) \text { vs DS }{ }^{d} \\
(94)\end{array}$ & 104 months & $\begin{array}{l}\text { FSS was associated only with a worse long- } \\
\text { term CSS compared with DS. }\end{array}$ & Larger tumor size. \\
\hline 2017 & $\begin{array}{l}\text { Brandon-Luke } \\
\text { L. Seagle }{ }^{5}\end{array}$ & GCT & 2680 & $\begin{array}{l}\text { I-IV (I I7I0, II } 256 \text { III } \\
235 \text { IVI0I, NR 358) }\end{array}$ & $\begin{array}{l}\text { Lymphadenectomy, } \\
\text { vs Non- } \\
\text { lymphadenectomy; } \\
\text { USO vs TAH-BSO }\end{array}$ & $\begin{array}{l}\text { Median (IQR) } \\
\text { follow-up } \\
\text { time was } 70.3 \\
\text { months } \\
\text { (range: } 41.5- \\
97.7 \text { months) }\end{array}$ & $\begin{array}{l}\text { I) Women without surgical lymph node } \\
\text { evaluation or with positive nodes had } \\
\text { decreased survival compared to women } \\
\text { with pathologically negative lymph nodes. } \\
\text { 2) Women who underwent only unilateral } \\
\text { oophorectomy had decreased survival } \\
((\mathrm{HR}(95 \% \mathrm{Cl}) \text { I.67 (I.26-2.22), } \\
\mathrm{P}<0.00 \mathrm{I})) \text {. }\end{array}$ & $\begin{array}{l}\text { Older age, more } \\
\text { comorbidities, prior } \\
\text { malignancy, higher stage, poor } \\
\text { differentiation, larger tumor } \\
\text { size, incomplete surgical } \\
\text { staging, residual disease. }\end{array}$ \\
\hline 2017 & $\begin{array}{l}\text { Hongyan } \\
\text { Cheng }^{53}\end{array}$ & MSCSTs & $\begin{array}{l}\text { Total } 72(\mathrm{GCTs} \\
\qquad \mathrm{n}=50)\end{array}$ & $\begin{array}{l}\text { Stage }(I-I I)(88.9 \%(n \\
=64)) \text {, advanced } \\
\text { stage }(I I I-I V)(I I . I \% \\
(n=8))\end{array}$ & $\begin{array}{l}\text { Lymphadenectomy, } \\
\text { vs Non- } \\
\text { lymphadenectomy }\end{array}$ & $\begin{array}{l}56.1 \text { months } \\
\text { (range: } 5-147 \\
\text { months) }\end{array}$ & $\begin{array}{l}\text { The } 5 \text { - and } 10 \text {-year overall survival rates } \\
\text { were the same: } 94.4 \% \text { in SCST and } 96.0 \% \\
\text { in GCT Lymphadenectomy showed no } \\
\text { statistically significant difference in overall } \\
\text { survival of patients with SCST or GCT (P = } \\
0.734 \text { and } 0.079 \text {, respectively). }\end{array}$ & Stage \\
\hline
\end{tabular}




\begin{tabular}{|c|c|c|c|c|c|c|c|c|}
\hline 2017 & $\begin{array}{l}\text { Dimitrios } \\
\text { Nasioudis } 52\end{array}$ & MSCSTs & 1156 & $\begin{array}{l}\text { Stage I (62\% IA, I.2\% } \\
\text { IB, I8.4\% IC, } 4.8 \% \\
\text { INOS) and Stage II } \\
(2.2 \% \text { IIA, } 7.9 \% \text { IIB, } \\
2.7 \% \text { IIC, } 0.7 \% \\
\text { IINOS) }\end{array}$ & $\begin{array}{l}\text { Lymphadenectomy, } \\
\text { vs Non- } \\
\text { lymphadenectomy }\end{array}$ & 95 months & $\begin{array}{l}\text { 1) Five-year OS was } 89.5 \% \text { and } 88.2 \% \text { for } \\
\text { patients that did or did not undergo LND, } \\
\text { respectively ( } \mathrm{P}=0.032 \text { from log-rank and } \\
\mathrm{P}=0.114 \text { from Breslow). However, OS was } \\
\text { not statistically different between patients } \\
\text { who did not undergo LND (LNDO) and } \\
\text { patients in each one of the LND groups. } \\
\text { 2) Five-year cancer-specific survival (CSS) } \\
\text { was similar, } 92.7 \% \text { and } 94.7 \% \text {, for patients } \\
\text { who did or did not undergo LND, } \\
\text { respectively. } \\
\text { 3) overall mortality did not differ between } \\
\text { the two groups after controlling for age, } \\
\text { histology and apparent stage. }\end{array}$ & Age, granulosa histology. \\
\hline 2019 & $\begin{array}{l}\text { Selçuk } \\
\text { Erkilınç55 }\end{array}$ & AGCT & 98 & I-III & $\begin{array}{l}\text { Lymphadenectomy, } \\
\text { vs Non- } \\
\text { lymphadenectomy } \\
(\mathrm{n}=46 \text { and } 52, \\
\text { respectively) }\end{array}$ & 48 months & $\begin{array}{l}\text { No significant difference was found in } \\
\text { recurrence rates between } \\
\text { lymphadenectomy and non- } \\
\text { lymphadenectomy groups ( } P=0.765 \text {; } \\
13.5 \% \text { and } 10.5 \% \text {, respectively). }\end{array}$ & $\begin{array}{l}\text { Number of cellular mitoses } \\
\geq 5 \text {, advanced tumor stage, } \\
\text { tumor size. }\end{array}$ \\
\hline 2018 & A. Bergamini ${ }^{58}$ & AGCTs & 223 & 1 & $\begin{array}{l}\text { Laparoscopic vs } \\
\text { open surgery }\end{array}$ & 81 months & $\begin{array}{l}\text { The present study suggests that surgical } \\
\text { route does not affect the oncological } \\
\text { safety of patients with stage I AGCT. }\end{array}$ & $\begin{array}{l}\text { Stage IC, incomplete staging } \\
\text { site of primary surgery. }\end{array}$ \\
\hline 2020 & $\begin{array}{l}\text { Masato } \\
\text { Yoshihara }^{30}\end{array}$ & SCSTs & $\begin{array}{c}77 \text { (67GCT } \\
\text { IOSTCT) }\end{array}$ & $\begin{array}{l}I(58 \%|A| 2|C| 5 \mid C 2 \\
2 \mid C 3)\end{array}$ & $\begin{array}{l}\text { Uterine-preserving } \\
\text { surgery group and } \\
\text { non-uterine- } \\
\text { preserving surgery } \\
\text { group, }\end{array}$ & 64.1 months & $\begin{array}{l}\text { 1) This study found that uterine-preserving } \\
\text { surgery did not have any impact on the } \\
\text { survival outcomes. 2) Uterine-preserving } \\
\text { surgery did not significantly affect the site } \\
\text { of tumour recurrence. }\end{array}$ & 1 \\
\hline
\end{tabular}

Notes: ${ }^{2} \mathrm{CSS}$, complete cytoreductive surgery (fertility-sparing surgery with unilateral salpingo-oophorectomy and endometrial curettage or total nonsparing hysterectomy, depending on the initial tumor stage and the menopausal status of the patient), combined with peritoneal staging surgery (omentectomy, peritoneal cytology, and multiple peritoneal biopsies). PCS: Compliance was partial in the case of complete cytoreductive surgery without peritoneal staging surgery. NCS: Non-compliance was defined by inadequate surgery according to the tumor stage and the patient's age. 'bSS:Fertility sparing surgery; USO:unilateral oophorectomy, CYS:cystectomy, CYS $\rightarrow$ USO:cystectomy and subsequently subjected to unilateral oophorectomy) RS: Hysterectomy and bilateral salpingectomy; ${ }^{\mathrm{C}} \mathrm{TAH}-\mathrm{BSO}$ : Hysterectomy and bilateral salpingectomy; ${ }^{\mathrm{d} D S}$ : Definitive surgery: Hysterectomy and bilateral salpingectomy; ${ }^{\mathrm{e} F S S:}$ preservation of the uterus and at least part of one ovary. RS: removal of both adnexa and the uterus, or both adnexa when the patient had a medical history of hysterectomy. 
Table 2 Summary of Recent Case Reports of MSCSTs

\begin{tabular}{|c|c|c|c|c|c|c|c|c|c|c|c|c|c|}
\hline $\begin{array}{l}\text { Published } \\
\text { Year }\end{array}$ & $\begin{array}{l}\text { First } \\
\text { Author }\end{array}$ & $\begin{array}{l}\text { No. of } \\
\text { Patients }\end{array}$ & $\begin{array}{l}\text { Age, } \\
\text { years }\end{array}$ & Symptoms & Tumor Type & Stage & Surgery & $\begin{array}{l}\text { Intraoperative } \\
\text { Findings }\end{array}$ & Chemotherapy & $\begin{array}{l}\text { Interval of } \\
\text { Recurrence }\end{array}$ & Site of Recurrence & $\begin{array}{l}\text { Treatment } \\
\text { After } \\
\text { Recurrence }\end{array}$ & $\begin{array}{l}\text { Follow-Up and } \\
\text { Status }\end{array}$ \\
\hline 2021 & $\begin{array}{l}\text { Man-Hua } \\
\mathrm{Cui}^{60}\end{array}$ & 2 & 35 & $\begin{array}{l}\text { Abdominal pain } \\
\text { Abdominal pain }\end{array}$ & . & IIIC & $\begin{array}{l}\text { TAH' and } \\
\text { bilateral } \\
\text { mastectomy }\end{array}$ & $\begin{array}{l}\text { Laparoscopic with } \\
\text { power morcellators } \\
10 \mathrm{~cm} \text { diameter mass } \\
\text { ovary presented } 720^{\circ} \\
\text { torsion frozen section } \\
\text { during surgery } \\
\text { suggested ovarian } \\
\mathrm{GCT}^{\circ}\end{array}$ & $\begin{array}{l}\text { None } \\
\\
\text { One cycle of CT' } \\
\text { (stop because of } \\
\text { severe } \\
\text { myelosuppression } \\
\text { (III degree). }\end{array}$ & 15 months & $\begin{array}{l}4 \text { disseminated niduses } \\
\text { around the LAPe port- } \\
\text { sites, peritoneal turn } \\
\text { over adjacent to the } \\
\text { bladder and left } \\
\text { abdominal wall. } \\
14.0 \mathrm{~cm} \times 9.0 \mathrm{~cm} \times 8.0 \mathrm{~cm} \\
\text { cystic mass was detected } \\
\text { intraoperatively at the } \\
\text { port-site, upper } \\
\text { abdominal cavity, pelvic } \\
\text { peritoneum, spleen, and } \\
\text { pancreas. }\end{array}$ & $\begin{array}{l}\text { Open abdominal } \\
\text { surgery TAH- } \\
\text { UsO', pelvic } \\
\text { LND', significant } \\
\text { omentum } \\
\text { resection, and } \\
\text { appendectomy, } \\
\text { and tumor cell } \\
\text { reduction+ } \mathrm{TC}^{\mathrm{m}} \text {. } \\
\text { Preoperative 6* } \\
\mathrm{CT} \text { 'open } \\
\text { abdominal } \\
\text { surgery the } \\
\text { pelvic mass, } \\
\text { whole spleen, } \\
\text { body and tail of } \\
\text { the pancreas, and } \\
\text { greater omentum } \\
\text { were resected } \\
+3^{*} \text { CT' after } \\
\text { surgery. }\end{array}$ & $\begin{array}{l}\text { No tumor } \\
\text { recurrence was } \\
\text { found during } 37 \\
\text { months follow-up. }\end{array}$ \\
\hline 2021 & $\begin{array}{l}\text { Li-juan } \\
\text { Huang }\end{array}$ & 1 & 61 & Vaginal bleeding & $\mathrm{SLCT}^{d}$ & Unkown & $\begin{array}{l}\text { Hysteroscopy } \\
\text { followed by } \\
\text { uterine curettage } \\
\text { was performed } \\
\text { (endometrial } \\
\text { polyp with } \\
\text { endometrial } \\
\text { typical } \\
\text { hyperplasia, and } \\
\text { cervical polyp) } \\
+ \text { LAP- TAH- } \\
\text { BSOB }\end{array}$ & $\begin{array}{l}\text { Left ovary } \\
3.0 \mathrm{~cm} \times 2.0 \mathrm{~cm} \times 1.0 \mathrm{~cm} \\
\text { frozen pathology } \\
\text { suggested possibility } \\
\text { of left SCSTP }\end{array}$ & None & 1 & 1 & 1 & $\begin{array}{l}\text { The patients were } \\
\text { tumor-free during } 9 \\
\text { months follow-up } \\
\text { visit. }\end{array}$ \\
\hline
\end{tabular}




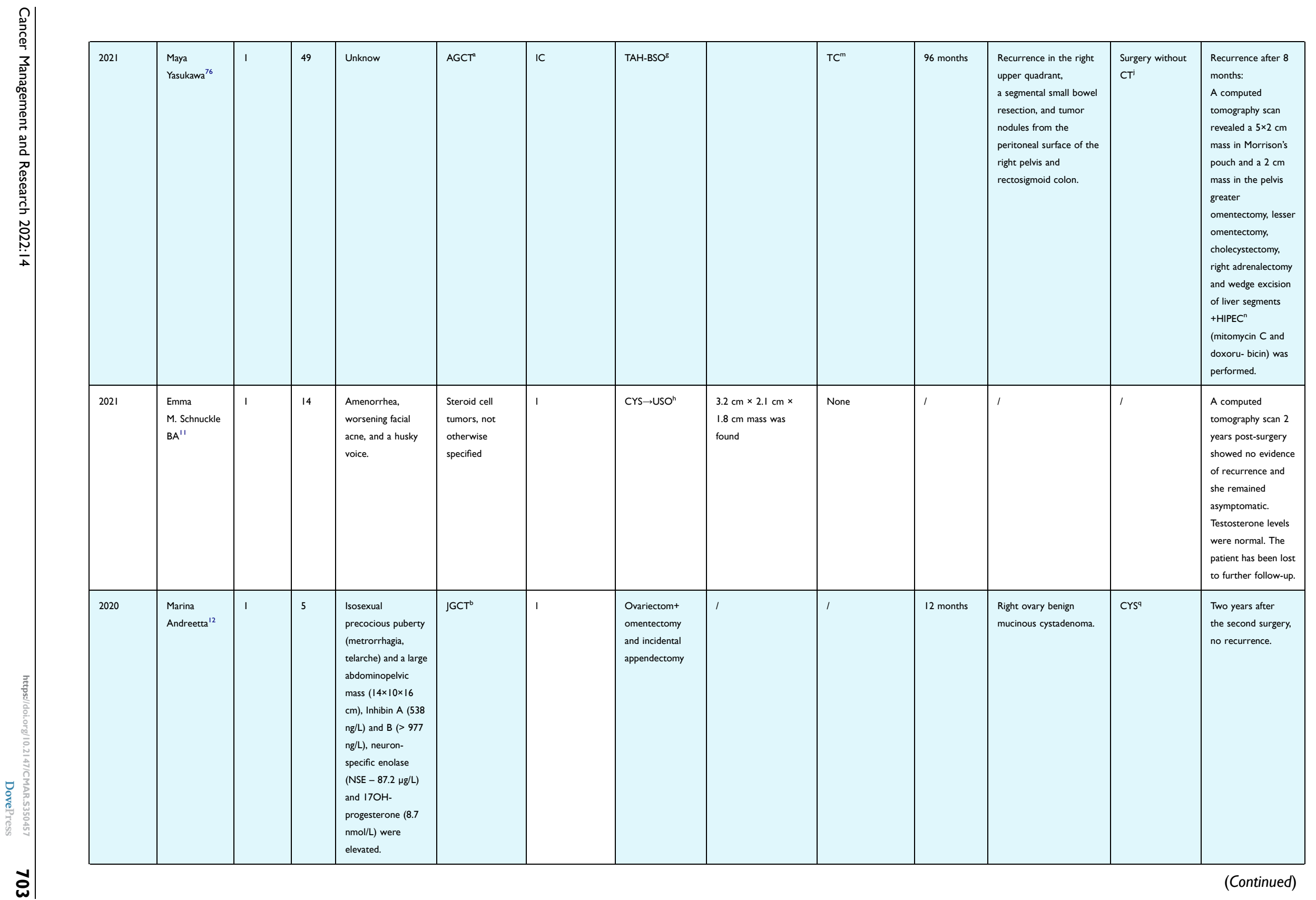


Table 2 (Continued)

\begin{tabular}{|c|c|c|c|c|c|c|c|c|c|c|c|c|c|}
\hline $\begin{array}{l}\text { Published } \\
\text { Year }\end{array}$ & $\begin{array}{l}\text { First } \\
\text { Author }\end{array}$ & $\begin{array}{l}\text { No. of } \\
\text { Patients }\end{array}$ & $\begin{array}{l}\text { Age, } \\
\text { years }\end{array}$ & Symptoms & Tumor Type & Stage & Surgery & $\begin{array}{l}\text { Intraoperative } \\
\text { Findings }\end{array}$ & Chemotherapy & $\begin{array}{l}\text { Interval of } \\
\text { Recurrence }\end{array}$ & Site of Recurrence & $\begin{array}{l}\text { Treatment } \\
\text { After } \\
\text { Recurrence }\end{array}$ & $\begin{array}{l}\text { Follow-Up and } \\
\text { Status }\end{array}$ \\
\hline 2020 & $\begin{array}{l}\text { Ivonete } \\
\text { Siviero' }\end{array}$ & 1 & 5 & Abdominal pain & $\mathrm{AGCT}^{\mathrm{a}}$ & IC & $\begin{array}{l}\text { Laparotomy } \\
\text { uso' }\end{array}$ & $7.5 \times 7.0 \times 5.0 \mathrm{~cm}$ mass & $4 * \mathrm{CT}^{\mathrm{T}}$ & 1 & 1 & 1 & $\begin{array}{l}\text { With normal tumor } \\
\text { markers (inhibin B) } \\
\text { and serial } \\
\text { ultrasonography } \\
\text { examinations in } 2 \\
\text { years of follow-up. }\end{array}$ \\
\hline 2020 & $\begin{array}{l}\text { Raffaele } \\
\text { Tinelli }^{62}\end{array}$ & 1 & 54 & 1 & $\mathrm{GCT}^{\mathrm{c}}$ & 1 & LAP'-USO' & 1 & I & 240 months & $\begin{array}{l}\text { Smooth surface, brown } \\
\text { colored, structure } \\
\text { developing under the } \\
\text { peritoneum of the } \\
\text { anterior pelvic wall near } \\
\text { the right inguinal canal } \\
\text { was observed. } 6 \mathrm{~cm} \text { cyst, } \\
\text { yellowish-brown, friable } \\
\text { developing under the } \\
\text { right anterior } \\
\text { peritoneum without } \\
\text { a clear cleavage plan from } \\
\text { the adipose tissue was } \\
\text { observed. }\end{array}$ & $\begin{array}{l}\text { Mass was } \\
\text { isolated and } \\
\text { removed+ } \\
\text { underwent } \\
\text { a second LAP - } \\
\text { procedure with } \\
\text { peritoneal } \\
\text { washing, a type } \\
\text { A radical TAH', } \\
\text { omentectomy, } \\
\text { appendectomy, } \\
\text { and pelvic and } \\
\text { para-aortic LND } \\
\text { with the superior } \\
\text { border of the } \\
\text { dissection being } \\
\text { the left renal } \\
\text { vein. }\end{array}$ & 1 \\
\hline 2019 & $\begin{array}{l}\text { Wiktor } \\
\text { Szewczuk' }\end{array}$ & 1 & 65 & $\begin{array}{l}\text { Vaginal bleeding for } \\
7 \text { years and a small } \\
\text { ovarian tumor } \\
(2 \mathrm{~cm} \text { in diameter) } \\
\text { was surprisingly } \\
\text { found on her right } \\
\text { ovary. }\end{array}$ & $\begin{array}{l}\text { AGCT }^{\mathrm{a}} \text { with } \\
\text { Endometrial } \\
\text { hyperplasia }\end{array}$ & 1 & $\begin{array}{l}\text { Laparoscopically } \\
\text { assisted vaginal } \\
\text { TAH }^{f}\end{array}$ & $\begin{array}{l}\text { Ovarian AGCT }{ }^{\mathrm{a}} \text { was } \\
\text { diagnosed intra- } \\
\text { operative }\end{array}$ & I & 1 & 1 & 1 & $\begin{array}{l}\text { Patients were free of } \\
\text { disease at I-year } \\
\text { follow-up. }\end{array}$ \\
\hline 2019 & $\begin{array}{l}\text { Sumaira } \\
\text { Qayoom's }\end{array}$ & 1 & 55 & $\begin{array}{l}\text { NO menstrual } \\
\text { complaints, solid- } \\
\text { cystic lesion } \\
\text { measuring } 93 \mathrm{~mm} \times \\
83 \mathrm{~mm} \times 64 \mathrm{~mm} \\
\text { was identified in the } \\
\text { left adnexa. }\end{array}$ & $\begin{array}{l}\text { Synchronous } \\
\text { infiltrating LBC } \\
\text { with GCT - } \\
\text { ovary }\end{array}$ & 1 & Uso' & $\begin{array}{l}\text { The left } \\
\text { oophorectomy } \\
\text { specimen showed } \\
\text { a solid cystic lesion } \\
\text { with a well-defined } \\
\text { solid nodule } \\
\text { measuring } 1.5 \mathrm{~cm} \times \\
1.0 \mathrm{~cm} \text {. }\end{array}$ & $\begin{array}{l}\text { 5-Fluorouracil, } \\
\text { epidoxorubicin, } \\
\text { and } \\
\text { cyclophosphamide } \\
\text { followed by } \\
\text { taxane. }\end{array}$ & I & I & 1 & $\begin{array}{l}\text { Doing fine for } \\
\text { almost a year. }\end{array}$ \\
\hline
\end{tabular}




\begin{tabular}{|c|c|c|c|c|c|c|c|c|c|c|c|c|c|}
\hline 2019 & $\begin{array}{l}\text { Sankeerthana } \\
\text { Kamanil' }\end{array}$ & 1 & 15 & $\begin{array}{l}\text { Amenor rhea, } \\
\text { gradual hair growth } \\
\text { over the face, chest } \\
\text { and back. }\end{array}$ & $\mathrm{SLCT}^{d}$ & IA & uso' & None & 1 & 1 & 1 & 1 & $\begin{array}{l}\text { Dramatic } \\
\text { improvement in } \\
\text { hirsutism after } 6 \\
\text { months. }\end{array}$ \\
\hline 2019 & Helen s. Xu & 1 & 33 & None & 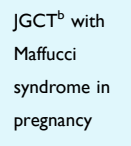 & IA & uso' & $\begin{array}{l}\text { Peritoneal washing } \\
\text { was negative for } \\
\text { malignant cells. }\end{array}$ & 1 & 1 & 1 & 1 & 1 \\
\hline 2018 & Liang Ma $^{18}$ & 1 & 19 & Massive ascites & JGCT ${ }^{b}$ & IC & uso' & 1 & $\begin{array}{l}6 * \mathrm{CT}^{\mathrm{j}} \text { with } \\
\text { Nedaplatin and } \\
\text { Paclitaxel } \\
\text { liposome. }\end{array}$ & 1 & 1 & I & $\begin{array}{l}6 \text { months to date } \\
\text { without recurrence. }\end{array}$ \\
\hline 2017 & $\begin{array}{l}\text { Mulat } \\
\text { Adefrisis }\end{array}$ & 1 & 50 & $\begin{array}{l}\text { Hirsutism and } \\
\text { hyperandrogenemia. }\end{array}$ & GCT $^{\mathrm{C}}$ & I & $\begin{array}{l}\text { TAH-BSO } \\
\text { resection of the } \\
\text { mass, infracolic } \\
\text { omentectomy, } \\
\text { and right pelvic } \\
\text { lymph node } \\
\text { sampling. }\end{array}$ & $\begin{array}{l}\text { Right ovary measured } \\
5 \times 4 \mathrm{~cm} \text {. Left ovary } \\
\text { was normal and no } \\
\text { ascites or culde-sac } \\
\text { fluid was seen. }\end{array}$ & 5 cycles of BEP & 19 months & 1 & I & $\begin{array}{l}\text { An ultrasound was } \\
\text { done once during } \\
\text { her follow-up and } \\
\text { was normal. }\end{array}$ \\
\hline 2018 & $\begin{array}{l}\text { Natasha } \\
\text { Rinn"9 }\end{array}$ & 1 & 39 & $\begin{array}{l}\text { Abdominal pain and } \\
\text { a right ovarian } \\
\text { mass. }\end{array}$ & $\mathrm{AGCT}^{\mathrm{a}}$ & IIIIC & $\begin{array}{l}\text { CYS } \rightarrow \text { USO }^{\text {h }} \\
\text { +staging } \\
\text { laparotomy } \\
\text { including right } \\
\text { UsO' } \\
\text { omentectomy } \\
\text { and stripping of } \\
\text { the pelvic } \\
\text { peritoneum. }\end{array}$ & $\begin{array}{l}\text { Omentum was } \\
\text { a smooth cystic mass } \\
\text { of } 2 \mathrm{~cm} \text { diameter. }\end{array}$ & None & 36 months & $\begin{array}{l}\text { Peritoneal stripping of } \\
\text { <3mm micropapillary } \\
\text { lesions in the pouch of } \\
\text { Douglas. }\end{array}$ & LAP'-surgery & $\begin{array}{l}\text { The patients } \\
\text { conceived } \\
\text { spontaneously and } \\
\text { had a normal } \\
\text { antenatal course, } \\
\text { and delivered } \\
\text { a female infant by } \\
\text { caesarean, } 7 \text { years } \\
\text { post initial diagnosis } \\
\text { with no signs of } \\
\text { recurrence. }\end{array}$ \\
\hline
\end{tabular}

(Continued) 
Table 2 (Continued).

\begin{tabular}{|c|c|c|c|c|c|c|c|c|c|c|c|c|c|}
\hline $\begin{array}{l}\text { Published } \\
\text { Year }\end{array}$ & $\begin{array}{l}\text { First } \\
\text { Author }\end{array}$ & $\begin{array}{l}\text { No. of } \\
\text { Patients }\end{array}$ & $\begin{array}{l}\text { Age, } \\
\text { years }\end{array}$ & Symptoms & Tumor Type & Stage & Surgery & $\begin{array}{l}\text { Intraoperative } \\
\text { Findings }\end{array}$ & Chemotherapy & $\begin{array}{l}\text { Interval of } \\
\text { Recurrence }\end{array}$ & Site of Recurrence & $\begin{array}{l}\text { Treatment } \\
\text { After } \\
\text { Recurrence }\end{array}$ & $\begin{array}{l}\text { Follow-Up and } \\
\text { Status }\end{array}$ \\
\hline 2018 & $\begin{array}{l}\text { Natasha } \\
\text { Rinn }{ }^{49}\end{array}$ & 1 & 34 & $\begin{array}{l}\text { Pelvic ultrasound } \\
\text { incidentally revealed } \\
\text { a 9-cm complex } \\
\text { cystic lesion on her } \\
\text { right ovary. }\end{array}$ & $\mathrm{GCT}^{\mathrm{c}}$ & IIB & $\begin{array}{l}\text { LAP-right ovarian } \\
\text { CYS without } \\
\text { rupture } \rightarrow \text { LAP } \\
\text { FSS-CS' was } \\
\text { performed, } \\
\text { which } \\
\text { demonstrated } \\
\text { the right ovary } \\
\text { adherent to the } \\
\text { ovarian fossa } \\
\text { requiring } \\
\text { peritoneal } \\
\text { stripping of the } \\
\text { right pelvic side } \\
\text { wall, with } \\
\text { salpingo- } \\
\text { ophrectomy and } \\
\text { infra-colic } \\
\text { omentectomy. }\end{array}$ & $\begin{array}{l}\text { Right ovary acherent } \\
\text { to the ovarian fossa } \\
\text { requiring peritoneal } \\
\text { stripping of the right } \\
\text { pelvic side wall. }\end{array}$ & None & 1 & 1 & 1 & $\begin{array}{l}\text { The patients became } \\
\text { pregnant } \\
\text { spontaneously and } \\
\text { delivered a female } \\
\text { infant by caesarean. } \\
\text { There was no } \\
\text { evidence of } \\
\text { recurrence at the } \\
\text { time of delivery. She } \\
\text { is currently } 18 \\
\text { months post initial } \\
\text { diagnosis with no } \\
\text { signs of recurrence. }\end{array}$ \\
\hline 2017 & $\begin{array}{l}\text { Heather } \\
\text { Katz }^{20}\end{array}$ & 1 & 48 & $\begin{array}{l}\text { Lower abdominal } \\
\text { pain }\end{array}$ & $\begin{array}{l}\mathrm{GCT}^{\mathrm{c}} \text { and } \\
\text { adrenocortical } \\
\text { carcinoma and } \\
\text { adenocarcinoma } \\
\text { of the colon }\end{array}$ & $\begin{array}{l}\text { Stage IA GCT', } \\
\text { a stage II } \\
\text { adrenocortical } \\
\text { carcinoma and } \\
\text { a stage III } \\
\text { adenocarcinoma } \\
\text { of the colon }\end{array}$ & $\begin{array}{l}\text { Laparotomy, } \\
\text { pelvic mass } \\
\text { resection, total } \\
\text { abdominal TAH- } \\
\text { BSO₹,bilateral } \\
\text { pelvic, LND }{ }^{k} \text {, } \\
\text { omentectomy. }\end{array}$ & $\begin{array}{l}\text { Pathology revealed } \\
\text { that the left pelvic } \\
\text { mass } 19 \times 18 \times 14 \mathrm{~cm} \\
\text { GCT }^{c}\end{array}$ & $\begin{array}{l}\text { FOLFOX }{ }^{\mp *} 6 \\
\text { cycles for her } \\
\text { stage III } \\
\text { adenocarcinoma of } \\
\text { the colon and } \\
\text { ultimately received } \\
12 \text { cycles. }\end{array}$ & 1 & 1 & 1 & $\begin{array}{l}\text { The patient is doing } \\
\text { well and has no sites } \\
\text { of recurrence or } \\
\text { metastatic disease. }\end{array}$ \\
\hline 2017 & $\begin{array}{l}\text { Tomomi } \\
\text { Isono21 }\end{array}$ & 1 & 75 & None & $\mathrm{GCT}^{\mathrm{C}}$ & Unknown & $\begin{array}{l}\text { Abdominal TAH- } \\
\text { BSOs }\end{array}$ & 1 & 1 & 72 months & Right diaphragm & $\begin{array}{l}\text { Right diaphragm } \\
\text { detected by } \\
\text { computed } \\
\text { tomography. }\end{array}$ & Unknown \\
\hline
\end{tabular}

Abbreviations: ${ }^{a} \mathrm{AGCT}$, adult granulosa cell tumor; ${ }^{\mathrm{b}} \mathrm{GCC}$, juvenile granulosa cell tumor; ${ }^{\mathrm{c} G C T}$, granulosa cell tumor; ${ }^{\mathrm{d} S L C T}$, Sertoli-Leydig cell tumor; ${ }^{\mathrm{C}} \mathrm{LAP}$, laparoscopic; ${ }^{\mathrm{f}} \mathrm{TAH}$, total hysterectomy; ${ }^{\mathrm{g}} \mathrm{TAH}-\mathrm{BSO}$, total hysterectomy and unilateral or bilateral salpingo-oophorectomy; ${ }^{\mathrm{h}} \mathrm{CYS} \rightarrow$ USO, cystectomy followed by unilateral salpingo-oophorectomy; 'USO, unilateral salpingo-oophorectomy; ${ }^{\mathrm{C} C T}$, chemotherapy; ${ }^{\mathrm{k}} \mathrm{LND}$, lymphadenectomy; 'FSS-CS, fertility sparing surgery with complete staging; ${ }^{\mathrm{m}} \mathrm{TC}$, carboplatin and paclitaxel; ${ }^{\mathrm{n}} \mathrm{HIPEC}$, hyperthermic intraperitoneal chemotherapy; ${ }^{\circ} \mathrm{BEP}$, bleomycin, etoposide, and cisplatin; ${ }^{\mathrm{P} S C S T}$, sex-cord stromal tumor; ${ }^{\mathrm{C}} \mathrm{CYS}$, cystectomy; ${ }^{\mathrm{F}} \mathrm{FOLFOX}$, 5-fluorouracil, leucovorin and oxaliplatin. 
Some other studies suggest that the performance of conservative surgery was not associated with recurrence and mortality. ${ }^{25-29}$ One study analyzed 113 patients with stage I AGCT aged less than 50 years, and there was no difference in DFS between patients who underwent FSS and RS. However, the study analyzed the FSS group separately, and it showed that the highest recurrence rate was observed in the group of patients treated with CYS-only, ${ }^{7}$ and this result is consistent with the results of the MITO study. ${ }^{4}$ This study also reported that 9 of 14 patients with CYS followed by USO or USO with staging were found with residual tumor cells in the preserved ovary, and two of them were upstaged. In patients who underwent CYS, the first episodes of recurrence were all in the ipsilateral ovary that had been preserved. ${ }^{7}$ This result shows that CYS-only may cause residual tumors and increase the risk of recurrence. A study in 2020 showed no difference in 10y recurrence-free survival (RFS) and 10-y OS between patients with stage I sex-cord stromal tumor (SCST) who underwent uterine-preserving surgery with a complete staging procedure and those who underwent hysterectomy with staging surgery. Also, uterine-preserving surgery had no effect the site of recurrence. Thus, the study concluded that uterine-preserving surgery may be possible for patients with stage I SCST. ${ }^{30}$

Some studies propose that FSS is safe for patients who desire fertility. A study shows that patients with non-epithelial ovarian cancer (NEOC) who underwent FSS have a lower recurrence rate and better 5-year progress-free survival (PFS). Although SCST accounts for $46.7 \%$, this finding has clinical implications. ${ }^{31}$ Further research is needed to confirm these findings.

Different proportions of different surgical procedures, different histologic subtypes, different stages of patients, and different age distributions could explain why those studies came to different conclusions.

In the above studies, except for the SEER-based study in 2017 and the study that analyzed the prognosis effect of uterine-preserving surgery in 2020, all other studies are focused on patients with GCT, especially AGCT. However, the histologic subtype may be associated with prognosis. Some studies said patients with GCT disease had better OS and cancer-specific survival than those with SLCT. ${ }^{32,33}$ Due to its rarity, few small sample size studies have been conducted to study the prognosis of patients with SLCT in recent years A retrospective study analyzed 23 patients with SLCT. It concluded that FSS was safe and effective for stage IA disease, but still controversial for stage IC patients. ${ }^{34}$ However, the study's sample size is too small, and the conclusion has little reference value.

The prognosis of patients varies at different stages. Except for the NCDB-based study, all other studies are focused on patients with stage I. Therefore, whether FSS is safe in patients with the advanced-stage disease is unclear. There are no large sample studies because of the low incidence rate of advanced-stage patients. However, the oncological and fertility outcomes of patients with advanced-stage disease are still optimistic in some reported cases. A patient with stage IIIC AGCT and mobilized omentum underwent USO and staging surgery, was conceived spontaneously and delivered via cesarean with no signs of recurrence 7 years after initial diagnosis. Another patient with stage IIB AGCT with pelvic peritoneum mobilized underwent CYS and complete staging, was also pregnant spontaneously and delivered an infant with no signs of recurrence 18 months post initial diagnosis (23).

FSS could be considered for young women with a high stage of juvenile granulosa cell tumor (JGCT). One patient with IIIB stage JGCT who underwent USO, omentectomy, and debulking surgery relapsed 55 months after the first optimal surgery. The patients underwent second debulking surgery as well as carboplatin and paclitaxel chemotherapy had no relapses in the 30-month follow-up period (24). Although the prognosis of those advanced-stage patients after conservative surgery is optimistic, surgical management of the advanced-stage disease should be decided in a multidisciplinary team (MDT) decision-making setting. ${ }^{35}$

According to a recent review, there have been 48 reported cases of gestational MSCST up to $2017 .^{22}$ SCST accounts for approximately $10-20 \%$ of ovarian malignancies diagnosed during pregnancy, ${ }^{36}$ with JGCT and SLCT being the most common identified subtypes. ${ }^{22}$ However, the majority of the patients exhibit no evident symptoms except when the tumor ruptures, and the majority of the ovarian tumors during pregnancy clinically present as a pelvic mass. Moreover, surgery during pregnancy is certainly associated with several risks; more than $90 \%$ of them are diagnosed with early-stage disease.

Thus, the management of ovarian tumors in pregnancy is challenging because of the fear of compromised fetal health and cancer risk. In general, surgical management prevails in the second trimester of pregnancy if tumor malignancy is suspected or when tumor size range from $6 \mathrm{~cm}$ to $8 \mathrm{~cm}$ and have a significantly higher risk of torsion ${ }^{37,38 .}$ Taking into 
account the favorable prognosis of stage I patients, the fertility-sparing surgical approach with optimal staging is recommended. Adnexectomy instead of cystectomy is preferred to avoid cyst rupture. A staging procedure is proposed when there is a high suspicion of invasive cancer. ${ }^{36}$ According to this review, the majority of cases underwent USO $(80.4 \%){ }^{36}$ According to a recent review, treatment was delayed for retention of pregnancy in $95.2 \%$ of the patients; nevertheless, serious adverse events occurred in a total of $40 \%$ of the cases including shock/hemoperitoneum (13.0\%), recurrence during pregnancy $(8.7 \%)$, rapid tumor progression $(2.2 \%)$, IUGR $(8.3 \%)$, maternal and/or neonatal death, and fetal loss $(6.3 \%)$ after surgery. ${ }^{22}$ However, those adverse outcomes were found entirely in patients with risk factors such as higher stage and older age. The fertility outcomes are generally good; the majority of patients achieve preservation of the fetus $(60.9 \%-77 \%){ }^{22,36}$ The five-year overall OS is about $89.3 \%$. The outcomes were excellent in patients with stage I, with 5-year survival rates totaling 100\%, but advanced stages (II-IV) were associated with decreased OS (5-year OS, stages II-IV versus stage I, $70 \%$ versus $100 \%, \mathrm{p}=0.008)$. Any serious adverse events during pregnancy were associated with a marginally decreased survival (5-year overall survival rate, yes versus no, $80.6 \%$ versus $100 \%, \mathrm{p}=0.077$ ). ${ }^{36}$ In summary, USO and complete staging procedure are feasible. The existing studies on the treatment show overall favorable fetal outcomes and OS; however, long-term data on children exposed to this treatment is needed to understand the downstream effects of the treatments, and multidisciplinary strategy to manage pregnancy complicated by MOSCT must be implemented.

\section{Oncological Prognosis: Impact of Complete Staging Procedure}

By summarizing the studies mentioned above, USO-only can be considered as a safe surgical procedure among fertilitydesired patients with an early stage. However, current guidelines suggest that complete staging procedure should be done regardless of whether or not FSS is performed, ${ }^{35,39}$ but it is still unclear that whether complete staging procedure can improve the prognosis.

Several studies have addressed the effect of complete staging procedure on the prognosis. Complete staging procedure, including peritoneal washing, inspections of peritoneal surfaces, random oriented multiple biopsies, and omentectomy, seems to be crucial in managing this tumor. ${ }^{7,40}$

Some studies suggest that incomplete staging gave significantly worse DFS and complete staging procedure needs to be performed in presumed early-stage GCT. In a retrospective study, stage I GCT patients who did not undergo staging surgery had poor DFS (HR 3.777 (1.409-10.123), P = 0.008). Significant differences in DFS were found between the patients who underwent USO and those who underwent USO with staging when women who underwent FSS were analyzed separately. ${ }^{7}$ The MITO study analyzed patients with stage IC GCT and drew a similar conclusion that incomplete staging surgery has a significant risk predictive value for recurrence $(\mathrm{RR}=2.19, \mathrm{P}=0.01) .{ }^{29}$ Another retrospective study separately analyzing GCT patients with early-stage (stage I-II) and advanced-stage (stage III-IV) found that 5-y DFS is better in stage I-II patients who underwent complete staging surgery group (100\% vs $94 \%$, $\mathrm{P}=$ 0.037). However, this study cannot analyze the impact of complete staging procedure on the recurrence of advancedstage patients because all those patients underwent CSS. ${ }^{41}$ Some studies suggest that for JGCT patients with high-risk factors such as germline PTEN and p53 overexpression, those who underwent USO with complete staging surgery may have a better prognosis than those who underwent USO only. However, only eight patients were included in the study due to the rarity of JGCT. More large-sample studies are needed to confirm these findings. ${ }^{42}$ Moreover, others reported that P53 overexpression is not associated with outcome, ${ }^{43}$ implying that more research is required.

Some authors hypothesized that patients who did not receive complete staging procedure may be due to unidentified occult metastatic disease and omitted chemotherapy in patients with risk factors. ${ }^{7}$ However, a negative resection margin could be achieved if the tumor-free principle is followed during operations. Chemotherapy's ability to improve survival is still debatable Furthermore, whether chemotherapy should be administered is not entirely determined by stage, and risk factors can be determined by preoperative evaluation and pathological reports.

Additionally, most of the isolated tumor recurrences can be effectively treated with complete tumor debulking if this procedure is possible, whereas the timely administration of chemotherapy or radiotherapy can effectively improve the survival of these patients. ${ }^{44}$ Besides, complete staging procedure may cause pelvic adhesion, which may diminish the rate of reproductive success and affect patients' quality of life. ${ }^{45}$ 
Moreover, some studies assumed that complete staging procedure could not improve the prognosis. In the TMRG and GINECO group studies, there were no significant differences in PFS, OS, and median survival time between patients with totally complete staging procedure and partially complete staging procedure in patients with $\mathrm{GCT}^{46}$

However, the existing studies have focused on patients with early-stage GCT. Future research is needed to analyze the role of complete staging procedure in patients with advanced-stage and other tumor subtypes.

\section{Restaging Surgery and Secondary Surgery}

However, some studies have found that tumors can recur in residual ovary tissue, ${ }^{47}$ and proper staging may allow better postoperative adjuvant treatment for the patients. Thus, some studies suggest that when childbearing is complete or those patients not wishing for immediate pregnancy or women with a higher stage of disease and postmenopausal women, TAH-BSO or restaging surgery may be warranted..$^{40,48,49}$ Furthermore, some studies emphasized the importance of secondary staging. A study showed that surgical restaging seems to upstage a considerable number of GCT, mainly in the initial stage IC group of patients $(34.5 \%){ }^{40}$ And patients with stage II or higher-stage disease had only microscopic extra-ovarian disease, ${ }^{24}$ which is difficult to estimate preoperatively. For example, a young patient with SLCT underwent FSS, and a tumor in the contralateral ovary was detected after subsequent complete staging surgery. A postmenopausal patient underwent a conservative surgical procedure and then underwent surgery for endometrial cancer, and the ovarian tumor was diagnosed at pathology. ${ }^{50}$

However, some studies suggested that the DSS and PFS of patients who underwent restaging surgery were similar to those who underwent observation only. ${ }^{27}$ The recurrence rates ranged from $9.8 \%$ to $27.4 \%$ in women who had FSS, ${ }^{51}$ the majority of patients did not require re-operation. Besides, the prognosis of secondary surgery plus chemotherapy after recurrence was good. The median time to the first relapse was 7.4 years, and $75 \%$ of relapses occurred about 10 years after initial diagnosis. ${ }^{47}$ Thus, life-long and close follow-up is essential. Delaying radical surgery until recurrence might be a choice.

\section{Lymphadenectomy}

Some studies reported that the lymph node metastasis rate was very low in MOSCST patients who underwent lymphadenectomy (range: $0-10.1 \%$ ). ${ }^{27,41,52-54}$ Another study said the lymph node metastasis rate was higher in patients with higher stage, and lymph node disease was detected among $23.3 \%$ and $26.9 \%$ of the women with stage III or IV disease, respectively. ${ }^{5}$ Although the NCCN guideline recognizes that lymphadenectomy can be excluded if there are no suspicious lymph nodes intraoperative, and the effect of lymphadenectomy on prognosis is still unclear.

A retrospective study indicated that complete lymphadenectomy may decrease the lymphatic recurrence rate and may provide tumoral debulking, because $76 \%$ of 158 AGCT patients underwent staging surgery, including lymphadenectomy. The total recurrence rate $(12.5 \%)$ of these patients was lower than the recurrence rate of patients in other studies. ${ }^{27}$ However, the clinicopathological characteristics of patients in different studies are heterogeneous, and recurrence is affected by numerous factors. Thus, the simple difference in recurrence rates could not explain the significance of lymphadenectomy. Another research also recommended lymphadenectomy among patients with GCT because patients with positive nodes or without surgical lymph node evaluation had lessened survival compared to those with pathologically negative lymph nodes. However, lymphadenectomy was only reported for 50.4\% (1350/2680) of patients, and only $3.1 \%(42 / 1350)$ of patients had positive lymph nodes. ${ }^{5}$ Some studies said 5-y OS was better for patients that did undergo lymphadenectomy compared with those who did not in early-stage (stage I-II) MOSCST patients (89.5\% vs $88.2 \%, \mathrm{P}=0.032),{ }^{52}$ while 5 -y OS was not different between patients who did not undergo lymphadenectomy and patients in each one of the lymphadenectomy groups separated according to the number of dissected lymph nodes. Moreover, 5-y cancer-specific survival did not fluctuate between the two groups after controlling for age, histology, and apparent stage. ${ }^{52}$

Several studies found that lymphadenectomy was not a prognostic factor both for DFS and OS. ${ }^{26,27,53,55}$ A Metaanalysis estimated pooled OR of lymphadenectomy was 0.87 (95\% CI, 0.57-1.31). ${ }^{53}$ Some studies found that lack of lymphadenectomy was significantly more common among patients with recurrence. However, lymphadenectomy was not associated with diminished recurrence rate and better survival in stage I AGCT. ${ }^{47}$ 
The significance of lymphadenectomy is not only to stage the tumor but also to reduce the tumor burden. Whether lymphadenectomy can help to lower the tumor burden depends on the patterns of metastasis. Some studies show that patterns of metastasis and the recurrence mechanism of MOSCSTs are spread either by a surface or hematogenous route instead of by a primary lymphatic spread. In a study, only 6 of $117(5 \%)$ patients had nodal involvement at the time of initial disease recurrence, while three of these six patients had no nodal involvement, and five of the six patients had multiple sites of metastatic disease. ${ }^{48}$ Another study showed that most nodal recurrences in patients with AGCT appear in a multifocal pattern. ${ }^{56}$ Thus, such recurrence may signify secondary spread of the tumor in other organs by surface spillage or hematogenous route rather than lymphatic spread or late growth of tumor cells present in nodal tissue. The rarity of lymphatic spread raises many questions, and further study will be required to understand the tumor biology and metastasis rate of MOSCSTs. ${ }^{48}$

Moreover, lymphadenectomy has many complications, such as lymphocytes, lymphangitis, edema of the legs, nerve and vessel injury, ureter and Intestinal injury, decreased hemoglobin level, constipation, increased wound infection, and chronic pelvic pain.

In conclusion, lymphadenectomy can be omitted if there are no suspicious lymph nodes preoperative or intraoperative. If lymph nodes are dissected, LODDS may be a more powerful predictor of survival than LNR. ${ }^{57}$ A study found that LODDS $>0.5$ was associated with a poorer prognosis; thus, for those patients with LODDS $>0.5$, more aggressive treatment and shorter follow-up intervals were recommended. ${ }^{32}$

\section{Surgical Route Selection}

Open surgery has long been considered the traditional surgical procedure. However, minimally invasive surgery in the direction of surgery is associated with reduced morbidity and hospitalization. ${ }^{58}$ Additionally, minimally invasive surgery in Gynecologic malignancies permits earlier administration of adjuvant therapy than traditional open surgery procedures. ${ }^{29}$ Thus, laparoscopic surgery has widely replaced the traditional open approach to such ovarian malignancies. $^{58}$

The MITO-9 study suggests no difference in DFS and OS between laparoscopic and open approaches among patients with stage I AGCT, ${ }^{58}$ and another study contributed to similar conclusion. ${ }^{3}$

Laparoscopic surgery is also feasible and efficient for restaging surgery, and there was no statistically significant difference between laparoscopy and open-surgery in terms of percentage of upstaged patients who underwent safer restaging surgery. ${ }^{40}$

However, some other studies said that minimally invasive surgery might be associated with a higher incidence of intraoperative tumor rupture and less thorough surgical staging. ${ }^{58}$ Moreover, $\mathrm{CO} 2$ gas in the abdomen would be discharged through the port-site, which provides an prospect for tumor fragments to accumulate. ${ }^{58-60}$ Protection measures can reduce those risks to some degree. Firstly, using an endo-bag container can effectively reduce this risk. ${ }^{58,60}$ Another study found that laparoscopy is comparable to the open approach for GCT with a size limit of 5$6 \mathrm{~cm}$ if the spillage is avoided by using a sterile plastic bag. ${ }^{61,62}$ Furthermore, some authors proposed that transvaginal natural orifice transluminal endoscopic surgery, such as surgery through the Douglas pouch may provide better cosmetic results and improve patient comfort. ${ }^{59}$ However, the safety of this surgical procedure for patients with malignant ovarian tumors needs to be further examined and explored. Gynecologists should comply with the tumor-free principle during surgery regardless of laparoscopic surgery and transabdominal surgery, ${ }^{63}$ and evaluation can be done according to Suidan's CT scores and Fagotti scores. A laparotomy should be done in addition to laparoscopy to avoid the spilling of tumors, especially in cases of larger masses.

For patients during pregnancy, surgical procedures can be performed by either laparotomy or laparoscopy, and some observational studies suggest that laparoscopic management of adnexal masses during pregnancy is related to a reduced risk of pregnancy complications. ${ }^{22}$ However, there is no available prospective evidence to evaluate these strategies during pregnancy.

In the case of MSCSTs, effective assessment modality, as well as efficacy and safety of minimally invasive surgery require further evaluation. 


\section{Fertility Outcomes}

Accurate conception rates and live birth rates after FSS remains ambiguous. There are also many factors influencing fertility, such as postoperative adhesions and psychosocial factors. ${ }^{45}$ Moreover, reported conception rates may be artificially low, because many of these studies do not distinguish between women who were unable to conceive and those who decided against attempting pregnancy but were unable to conceive. Among women with GCT who underwent FSS, pregnancy rates were only $10 \%{ }^{5} \mathrm{~A}$ multicenter retrospective study showed that the pregnancy rate was about $16.7 \%$ among AGCT patients and about $36.4 \%$ among JGCT patients. ${ }^{28}$

However, some other studies suggest that the pregnancy outcomes are optimistic. In a systematic review, pregnancy and live birth rates are encouraging in non-epithelial ovarian carcinoma (NEOC). The pregnancy rate varied from $50 \%$ to $93 \%$, and the live birth rate ranged from $65 \%$ to $95 \% .{ }^{64}$ And another study found that the pregnancy rate was $86.4 \%$ and the live birth rate was $95 \%$ among 22 stage I GCT patients desiring pregnancy, even those who received adjuvant chemotherapy. ${ }^{7}$

Pregnancy or even delivery may not affect recurrence or death. ${ }^{65}$ Some studies even suggest that the suppression of follicle-stimulating hormone (FSH) noticed in pregnancy, which causes downregulation of granulosa cells, would improve the prognosis of patients with GCT. ${ }^{49}$ The study also suggested that oral contraceptives (OCP) can also suppress FSH; thus, OCP can be used in those patients not wishing for immediate pregnancy. ${ }^{49}$ However, its effectiveness and safety require further research.

IVF therapy is necessary in some cases. Ovaries containing GCT respond to gonadotropin stimulation and may cause the contralateral ovary with intra-ovarian tumor volume to increase during therapy. Thus, local tumor residue should be avoided.

Premenopausal patients might suffer from menopausal symptoms after radical surgery. Hormone replacement therapy (HRT) may reduce the risk of the progression of GCT. ${ }^{47}$ Moreover, no study has demonstrated a deleterious effect of menopausal HRT. ${ }^{66}$ Thus, there is no need to limit postmenopausal HRT use for patients with treated AGCT, and further studies are needed.

To sum up, fertility outcomes are relatively optimistic, although affected by many confounders. Pregnancy or even delivery may not affect recurrence or death, and tumor residue should be avoided before IVF-ET. OCP can be used in patients who do not have recent fertility requirements. HRT may be feasible to manage patients with menopausal symptoms after completing surgery. Further research is necessary to evaluate the effectiveness and safety of these therapies.

\section{Endometrial Evaluation}

Moreover, $12.50-26.2 \%$ of the GCT patients had simple hyperplasia. ${ }^{25,67}$ Approximately 5\% of AGCT patients had complex hyperplasia with or without atypia, and $1-25.5 \%$ had adenocarcinoma. ${ }^{25,68,69}$ Therefore, all fertility preservation patients with GCT should have a thorough endometrial evaluation, especially in patients older than 40 years old and with symptoms like abnormal uterine bleeding. ${ }^{67,68}$

\section{Chemotherapy}

Some studies suggest that chemotherapy can improve the survival of patients with MOSCSTs. A study based on the NCDB shows that patients with stages III-IV malignant non-GC SCST who received chemotherapy had a longer median overall survival time. ${ }^{70}$ However, NCDB does not collect information on tumor recurrence and the cause of death; thus, this study could not analyze differences in relapse, PFS, and cancer-specific survival. Besides, information on residual disease, a crucial prognosis factor, especially for advanced-stage patients, is also incomplete. Furthermore, no benefit of chemotherapy was demonstrated in a previous analysis of the NCDB, for patients with stage III-IV granulosa cell tumors. ${ }^{5}$ Thus, the efficacy of chemotherapy on patients with advanced-stage disease needs further verification.

Several studies found that chemotherapy has no effect on prognosis. Chemotherapy had no discernible benefit in terms of overall survival for patients with stage I-II malignant non-GC SCST, even in those with grade III tumor. ${ }^{70}$ Another study showed no significant difference in OS between the two groups in patients with stage II-IV SCST. ${ }^{52}$ 
A retrospective study showed that chemotherapy was not associated with improved DFS in patients with stage IC $\mathrm{AGCT}^{71}$ which was consistent with the findings of the study in MITO centers. ${ }^{29}$

A recent study that analyzed postoperative SCST patients from the SEER database revealed that chemotherapy had a reverse effect on OS. Analysis stratified by stage found that stages IA and IB patients who received chemotherapy had poor OS, while OS showed no significant difference in patients with other stages. ${ }^{72}$ This deleterious effect of chemotherapy may be due to ineffective chemotherapeutic regimens, side effects, and individual differences in patients' tolerance to chemotherapy. The unfavorable results of chemotherapy indicate the need for further exploration.

The majority of studies concluded that the number of chemotherapy cycles had no effect on recurrence, ${ }^{71}$ but one study suggests that at least six cycles of bleomycin, etoposide, and cisplatin (BEP) chemotherapy after optimal cytoreduction may be the best treatment for patients with stage III-IV GCT. ${ }^{41}$ However, it is difficult to make any reliable prognosis evaluation according to different chemotherapy regimens. ${ }^{73}$ The BEP regimen is currently the most widely used for NEOC. However, given that serious pulmonary toxicity and even death have been reported in GCT patients in association with high-dose bleomycin. ${ }^{74}$ The Gynecologic Oncology Group is currently recruiting women with advanced or recurrent ovarian granulosa cell-tumor for a randomized Phase II trial of carboplatin-paclitaxel compared to BEP, with a primary outcome of progression-free survival (NCT01042522). The expectation is that treatment with carboplatin and paclitaxel will be associated with reduced toxicity and similar progression-free survival compared to treatment with BEP.

For pregnant women with MOSCSTs, indications for adjuvant chemotherapy are the same as for nonpregnant patients, ${ }^{38}$ and systemic chemotherapy is not administered in the first trimester to avoid miscarriage and congenital malformations. Paclitaxel-carboplatin or cisplatin-vinblastine-bleomycin (PVB) chemotherapy with reduced toxicity is more appropriate than BEP. ${ }^{38} \mathrm{~A}$ review shows that the combination of cisplatin/cyclophosphamide with or without epirubicin was the treatment of choice in most cases. ${ }^{22}$ The existing studies on chemotherapy demonstrate overall favorable fetal outcomes. Nevertheless, long-term data on children exposed to chemotherapy is needed to understand the downstream effects.

Further research into postoperative adjuvant chemotherapy and its efficacy is needed.

\section{Treatment for Recurrence Patients}

Multifocal disease at first recurrence and incomplete resection of recurrence disease were associated with diminished OS. Thus, surgery should be the mainstay of treatment for patients with recurrence, with the aim of no residual disease. ${ }^{75}$ Some authors suggest that cytoreductive surgery (CRS) plus hyperthermic intraperitoneal chemotherapy (HIPEC) can be an efficient therapeutic option for women with recurrent $\mathrm{GCT} .{ }^{76}$ Isolated case reports and small case studies suggest that chemotherapy can achieve long-term remission in patients with recurrent JGCT. ${ }^{77}$

Besides, anti-angiogenic treatment, hormonal therapy, and targeted therapy have a certain therapeutic efficacy in patients with relapse. Vascular endothelial growth factor (VEGF) expression is common in GCT. Some studies say that bevacizumab is an active agent in recurrent SCST combined with other agents. The authors reported a $16.7 \%$ response rate and a median PFS of 9.3 months (95\% CI 4.1-15 months) in the 36 patients accrued. ${ }^{78}$ However, bevacizumab should be avoided during pregnancy, because of insufficient evidence regarding its use during pregnancy. ${ }^{38}$

Despite limited available data, hormone therapy appears to be a useful alternative treatment for patients with advanced-stage or recurrent AGCTs. A study showed that $18 \%$ of the patients had an objective response to HT. ${ }^{79}$ Another author pool-analyzed the results of all case reports and case series and found an objective response rate of $71 \%$ HT in patients with an ovarian GCT. ${ }^{80}$ The treatment modalities have incorporated medroxyprogesterone acetate (MPA) (a synthetic progestogen), megestrol acetate (a steroidal progestin), a selective estrogen receptor modulator (SERM), diethylstilbestrol (DES) (a synthetic nonsteroidal estrogen), gonadotropin-releasing hormone agonist (GnRH-a) and aromatase inhibitors (AIs), etc. ${ }^{81,82}$ Patients had prolonged remissions (14-42 months) after being treated with high doses of MPA. Sequential therapy may prolong the anti-proliferative effects of progestin by promoting regeneration and stimulation of progesterone receptors. ${ }^{81}$ A review suggests that AIs as well as MPA, megestrol acetate alternating with tamoxifen, and DES had a $100 \%$ response rate. ${ }^{80}$ Some studies also recommend GnRH-a for ovarian function protection during chemotherapy, although the efficacy of GnRH-a for the prevention of ovarian toxicity is still controversial. ${ }^{83}$ AIs 
identified by far the most effective agents, ${ }^{80}$ and the use of anastrozole and letrozole resulted in remissions ranging from 12 to 54 months. ${ }^{82}$ In a recent multicentre phase II PARAGON trial (ANZGOG-0903), the role of AIs for relapsed granulosa cell tumors is being assessed ${ }^{44}$ A pre-clinical study investigating a panel of tyrosine kinase inhibitors (TKIs) in two human granulosa cell lines demonstrated dose-dependent inhibition with the multi-targeted TKI, sorafenib, but not sunitinib or an RAF-1 kinase inhibitor. The authors suggested that v-RAF murine sarcoma viral oncogene homolog B1 (BRAF) inhibition may represent an additional useful strategy in the treatment of GCT. ${ }^{84}$ Clinical investigation of sorafenib or possibly a more potent BRAF inhibitor, such as vemurafenib or dabrafenib, should be warranted.

\section{Prognosis Factors}

Stage is currently the widest approved prognostic factor. ${ }^{3,26,27,52,55,85}$ A study said that in stage IC patients, significantly more recurrences occurred in patients lacking staging surgery or adjuvant chemotherapy and that these patients might benefit from a more aggressive initial treatment approach. ${ }^{47}$

In some studies, younger age may be associated with better OS, $, 32,52$ and DFS. ${ }^{27}$ GCT patients $<50$ years old had a $9 \%$ survival advantage over their older cofounders. ${ }^{3}$ Another study shows that people older than 60 years were the risk factors that remained significant. ${ }^{26}$ Thus, some studies suggest that older patients should also be treated intensively if their physical condition allows them to improve their survival status. ${ }^{32}$ Those different results may be attributed to the heterogeneous populations and different cut-offs; thus, these factors need to be further elucidated. Menopausal status may also be associated with recurrence. ${ }^{25,27}$ However, some studies show that younger age and premenopausal status at the time of primary diagnosis increase the risk for recurrence. ${ }^{47}$ These controversial conclusions may be attributed to the following reasons: First, menstrual status is associated with age, which is a prognosis factor. Besides, where estrogen levels are higher in premenopausal females, the risk of recurrence may be higher than that of patients with menopausal status. Moreover, these premenopausal women are often treated with FSS.

Tumor size is also a prognosis factor. Each one-centimeter increase in tumor size was associated with a 4\% (2-6\%) increased risk of death in women with stage I GCT. ${ }^{5,24}$ Some studies found that all the patients with tumors smaller than $7 \mathrm{~cm}$ had no tumor recurrence. ${ }^{24}$ Some studies suggest that tumors larger than $10 \mathrm{~cm}$ may be a risk factor for cancerspecific survival. ${ }^{5,26,32}$ However, no survival benefit was observed for the TAH-BSO in women with tumors greater than $10 \mathrm{~cm} .{ }^{23}$ A reason for this poor prognosis may be the biological characteristics of large tumors. However, some studies show that tumor diameter was not associated with recurrence. In some studies, there was no difference in 5-y DFS between patients with tumors larger than $10 \mathrm{~cm}$ and those with tumors less than $10 \mathrm{~cm} .{ }^{85}$ Further studies should be required to evaluate risk factors in patients with large tumors.

Patients with CA125 negative had a better 10-year OS than those with CA125 positive. ${ }^{32}$ Ovarian tumors characterized by hyperandrogenemia might predict a better prognosis. ${ }^{86}$

The residual tumor may be associated with an increased risk of death,${ }^{5}$ but some studies suggest that after accounting for stage and age at diagnosis in a study of GCT, this finding was no longer relevant in multivariate analysis. ${ }^{3,26,67}$ Another study did not find any impact on the survival of postoperative residual disease. ${ }^{85}$ Cyst rupture is a strong predictive factor for recurrence. ${ }^{27,47}$ However, there was no difference between the patients having a spontaneous or iatrogenic cyst rupture in terms of recurrence. ${ }^{25}$ In contrast, some studies believe that tumor rupture has no impact on survival. ${ }^{85}$ The presence of ascites, but the volume of the ascites was not associated with recurrence. ${ }^{27}$

According to some studies, GCT has a better OS than non-GCT. ${ }^{52}$ Prognosis also depends on tumor differentiation. ${ }^{5,25,27}$ Recurrence was associated with the presence of heterologous elements and a retiform pattern, ${ }^{87}$ a poorly differentiated tumor. ${ }^{27}$ The number of cellular mitoses $\geq 5$ was independent of the poor prognostic factor for DFS and OS. ${ }^{55}$ SCST patients who have the TERT mutation, have more aggressive disease and worse overall survival. Ollier disease and Maffucci syndrome are associated with an increased risk of JGCTs. More comorbidities were associated with an increased risk of death. ${ }^{5}$

\section{Undergoing Study}

Only seven undergoing studies are about MOSCST registered in the US Clinical Trials Database, and six of those studied are about adjuvant chemotherapy and other targeted therapies for advanced or disseminated tumors. A study assessing the 
quality of life and the late sequelae of chemotherapy is in process. No ongoing studies are investigating the impact of different surgical procedures on the prognosis of patients with MOSCSTs.

\section{Conclusion}

In summary, USO-only seems to be feasible in patients with early-stage MOSCSTs, while CYS-only is avoided. FSS with staging seems to be safe and effective in patients with advanced-stage disease, and the decision on surgery of an advancedstage tumor should be taken in an MDT decision-making setting. Complete staging procedure can be omitted in early-stage patients without risk factors on the basis of perfect preoperative evaluation and the tumor-free principle. Long-term followup is essential. Delaying radical surgery until recurrence might be a choice. Lymphadenectomy can be omitted if there are no suspicious lymph nodes preoperative or intraoperative. Endometrial evaluation should be done on patients older than 40 years old and on patients with symptoms. Laparoscopic surgery is feasible and efficient if the tumor-free principle during surgery should be complied with other subtypes of this tumor. Currently, there is limited research available on advancedstage diseases. The effects of chemotherapy, targeted treatment, and hormonal therapy are still controversial. Multicenter, large randomized trials, or reanalysis of these questions with another very large cohort are needed.

\section{Abbreviations}

AGCT, adult granulosa cell tumor; AIs, aromatase inhibitors; BEP, bleomycin, etoposide and cisplatin; BRAF, v-RAF murine sarcoma viral oncogene homolog B1; BSO, bilateral salpingo-oophorectomy; CSS, cancer-specific survival; CSS, complete staging surgery; CT, chemotherapy; CYS, cystectomy; DES, diethylstilbestrol; DFS, disease-free survival; EP, etoposide and cisplatin; FIGO, International Federation of Gynaecology and Obstetrics; FSH, follicle-stimulating hormone; FSS, fertility-spring surgery; GCT, granulosa cell tumor; GnRH-a, gonadotrophin releasing hormone agonist; HT, hormone therapy; HRT, hormone replacement therapy; IUGR, intrauterine growth retardation; JGCT, Juvenile granulosa cell tumor; LND, lymphadenectomy; LODDS, log odds of positive lymph nodes; MOSCSTs, malignant ovarian sex cord-stromal tumors; MPA, medroxyprogesterone acetate; NCCN, National Comprehensive Cancer Network; NCDB, National Cancer Database; Non-CT, non-chemotherapy; NEOC, non-epithelial ovarian cancer; Non-GC SCST, non-granulosa cell sex cordstromal tumors; OCP, oral contraceptives; OS, overall survival; PFS, progression-free survival; PVB, cisplatin-vinblastinbleomycin; RS, radical surgery; SCST, sex cord-stromal tumor; SEER, Surveillance, Epidemiology, and End Results; SERM, selective estrogen receptor modulator; SLCT, Sertoli-Leydig cell tumor; SO, salpingo-oophorectomy; TAH-BSO, hysterectomy and bilateral salpingo-oophorectomy; TC, carboplatin with paclitaxel; FSS, fertility spring surgery; TKIs, tyrosine kinase inhibitors; USO, unilateral salpingo-oophorectomy; VEGF, vascular endothelial growth factor.

\section{Author Contributions}

All authors of our article made a significant contribution in the conception, design, literature search, execution, acquisition, analysis and interpretation, took part in drafting, revising or critically reviewing the article; gave final approval of the version to be published; have agreed on the journal to which the article has been submitted; and agree to be accountable for all aspects of the work.

\section{Funding}

There is no funding to report.

\section{Disclosure}

The authors declare that they have no competing interests.

\section{References}

1. Ray-Coquard I, Brown J, Harter P, et al. Gynecologic Cancer InterGroup (GCIG) consensus review for ovarian sex cord stromal tumors. Int J Gynecol Cancer. 2014;24(9 Suppl 3):S42-47.

2. Al Harbi R, McNeish IA, El-Bahrawy M. Ovarian sex cord-stromal tumors: an update on clinical features, molecular changes, and management. Int J Gynecol Cancer. 2021;31(2):161-168. 
3. Mangili G, Ottolina J, Gadducci A, et al. Long-term follow-up is crucial after treatment for granulosa cell tumours of the ovary. Br $J$ Cancer. 2013;109(1):29-34.

4. Bergamini A, Cormio G, Ferrandina G, et al. Conservative surgery in stage I adult type granulosa cells tumors of the ovary: results from the MITO-9 study. Gynecol Oncol. 2019;154(2):323-327.

5. Seagle BL, Ann P, Butler S, Shahabi S. Ovarian granulosa cell tumor: a National Cancer Database study. Gynecol Oncol. 2017;146(2):285-291.

6. van Heerden J, Tjalma WA. The multidisciplinary approach to ovarian tumours in children and adolescents. Eur J Obstet Gynecol Reprod Biol. 2019;243:103-110.

7. Wang D, Cao D, Jia C, et al. Analysis of oncologic and reproductive outcomes after fertility-sparing surgery in apparent stage I adult ovarian granulosa cell tumors. Gynecol Oncol. 2018;151(2):275-281.

8. Akbarzadeh-Jahromi M, Aslani FS, Raeisi H, Momtahan M, Taheri N. Comparison of Frozen and Permanent Section Diagnosis in Ovarian Neoplasms: analysis of Factors Affecting Accuracy. Int J Gynecol Pathol. 2021;1:635.

9. Durmuş Y, Kılıç Ç, Çakır C, et al. Sertoli-Leydig cell tumor of the ovary: analysis of a single institution database and review of the literature. J Obstet Gynaecol Res. 2019;45(7):1311-1318.

10. Huang LJ, Shi LY, Duan J. Clinicopathological analysis of ovarian Sertoli-Leydig cell tumor with postmenopausal vaginal bleeding as the first symptom: a case report. Medicine. 2021;100(13):e24922.

11. Schnuckle EM, Williamson A, Carpentieri D, Taylor S. Ovarian sex cord stromal tumor, steroid cell, NOS in an adolescent: a case report. J Pediatr Adolesc Gynecol. 2021;34(1):94-97.

12. Andreetta M, Dall'Igna P, De Corti F, Gamba P, Virgone C. Metachronous contralateral cystadenoma after ovariectomy for juvenile granulosa cell tumor in a young girl: an uncommon association. J Pediatr Adolesc Gynecol. 2021;34(1):103-105.

13. Siviero I. da Silva de Oliveira JT, Forny DN, et al. Torsion of granulosa cell tumor of the ovary in a preschool patient: a rare cause of acute abdomen. Am J Case Rep. 2020;21:e921689.

14. Szewczuk W, Szewczuk O, Czajkowski K, Grala B, Semczuk A. Ovarian adult-type granulosa cell tumor concomitant with simple endometrial hyperplasia: a case study with selected immunohistochemistry. J Int Med Res. 2020;48(4):300060519886984.

15. Qayoom S, Kumari M, Gupta S, Goel M. Synchronous occurrence of lobular breast carcinoma and granulosa cell tumor of ovary mimicking metastatic lobular breast carcinoma. J Cancer Res Ther. 2019;15(5):1186-1188.

16. Kamani S, Sampathkumar G, Asirvatham AR, Balachandran K. Sertoli-Leydig cell tumour in a patient with non-classic congenital adrenal hyperplasia: an uncommon duo. BMJ Case Rep. 2019;12:9.

17. Xu HS, Zhong E, Rotman J. Juvenile granulosa cell tumor associated with Maffucci syndrome in pregnancy: a case report. Clin Imaging. 2019;56:77-80.

18. Ma L, Zhang L, Zhuang Y, Ding Y, Chen J. A rare case report of ovarian juvenile granulosa cell tumor with massive ascites as the first sign, and review of literature: case report and review of literature. Medicine. 2018;97(25):e10916.

19. Adefris M, Fekadu E. Postmenopausal mild hirsutism and hyperandrogenemia due to granulosa cell tumor of the ovary: a case report. $J$ Med Case Rep. 2017;11(1):242.

20. Katz H, Jafri H, Brown L, Pacioles T. Triple synchronous primary malignancies: a rare occurrence. BMJ Case Rep. 2017;2017:654.

21. Isono T, Tanaka H, Fan M, et al. Metastatic ovarian granulosa cell tumor of the diaphragm resected by video-assisted thoracoscopic surgery;report of a case. Kyobu Geka. 2017;70(2):139-142.

22. Boussios S, Moschetta M, Tatsi K, Tsiouris AK, Pavlidis N. A review on pregnancy complicated by ovarian epithelial and non-epithelial malignant tumors: diagnostic and therapeutic perspectives. J Adv Res. 2018;12:1-9.

23. Nasioudis D, Frey MK, Chapman-Davis E, Witkin SS, Holcomb K. Safety of fertility-sparing surgery for premenopausal women with sex cord-stromal tumors confined to the ovary. Int J Gynecol Cancer. 2017;27(9):1826-1832.

24. Thrall MM, Paley P, Pizer E, Garcia R, Goff BA. Patterns of spread and recurrence of sex cord-stromal tumors of the ovary. Gynecol Oncol. 2011;122(2):242-245.

25. Thomakos N, Biliatis I, Koutroumpa I, et al. Prognostic factors for recurrence in early stage adult granulosa cell tumor of the ovary. Arch Gynecol Obstet. 2016;294(5):1031-1036.

26. Bryk S, Farkkila A, Butzow R, et al. Clinical characteristics and survival of patients with an adult-type ovarian granulosa cell tumor: a 56-year single-center experience. Int J Gynecol Cancer. 2015;25(1):33-41.

27. Karalok A, Turan T, Ureyen I, et al. Prognostic factors in adult granulosa cell tumor: a long follow-up at a single center. Int $J$ Gynecol Cancer. 2016;26(4):619-625.

28. Lee IH, Choi CH, Hong DG, et al. Clinicopathologic characteristics of granulosa cell tumors of the ovary: a multicenter retrospective study. J Gynecol Oncol. 2011;22(3):188-195.

29. Mangili G, Ottolina J, Cormio G, et al. Adjuvant chemotherapy does not improve disease-free survival in FIGO stage IC ovarian granulosa cell tumors: the MITO-9 study. Gynecol Oncol. 2016;143(2):276-280.

30. Yoshihara M, Tamauchi S, Iyoshi S, et al. Does uterine preservation affect survival outcomes of patients with stage I ovarian sex cord-stromal cell tumours? A multi-institutional study. Eur J Obstet Gynecol Reprod Biol. 2020;254:52-56.

31. Johansen G, Dahm-Kähler P, Staf C, Flöter Rådestad A, Rodriguez-Wallberg KA. Fertility-sparing surgery for treatment of non-epithelial ovarian cancer: oncological and reproductive outcomes in a prospective nationwide population-based cohort study. Gynecol Oncol. 2019;155 (2):287-293

32. Wang JY, Li J, Chen RF, Lu X. Contribution of lymph node staging method and prognostic factors in malignant ovarian sex cord-stromal tumors: a world wide database analysis. Ejso. 2018;44(7):1054-1061.

33. Nasioudis D, Mastroyannis SA. A FH, E MK, Latif NA. Ovarian Sertoli-Leydig and granulosa cell tumor: comparison of epidemiology and survival outcomes. Arch Gynecol Obstet. 2020;302(2):481-486.

34. Gouy S, Arfi A, Maulard A, et al. Results from a monocentric long-term analysis of 23 patients with ovarian Sertoli-Leydig cell tumors. Oncologist. 2019;24(5):702-709.

35. Sessa C, Schneider DT, Planchamp F, et al. ESGO-SIOPE guidelines for the management of adolescents and young adults with non-epithelial ovarian cancers. Lancet Oncol. 2020;21(7):e360-e368. 
36. Blake EA, Carter CM, Kashani BN, et al. Feto-maternal outcomes of pregnancy complicated by ovarian sex-cord stromal tumor: a systematic review of literature. Eur J Obstet Gynecol Reprod Biol. 2014;175:1-7.

37. Chang SD, Yen CF, Lo LM, Lee CL, Liang CC. Surgical intervention for maternal ovarian torsion in pregnancy. Taiwan J Obstet Gynecol. 2011;50 (4):458-462.

38. Amant F, Halaska MJ, Fumagalli M, et al. Gynecologic cancers in pregnancy: guidelines of a second international consensus meeting. Int $J$ Gynecol Cancer. 2014;24(3):394-403.

39. Morgan RJ. NCCN clinical practice guidelines in oncology-ovarian cancer including fallopian tube cancer and primary peritoneal cancer. Version. 2021;5:256.

40. Peiretti M, Candotti G, Fais ML, et al. Comparison between laparoscopy and laparotomy in the surgical re-staging of granulosa cell tumors of the ovary. Gynecol Oncol. 2020;157(1):85-88.

41. Park JY, Jin KL, Kim DY, et al. Surgical staging and adjuvant chemotherapy in the management of patients with adult granulosa cell tumors of the ovary. Gynecol Oncol. 2012;125(1):80-86.

42. Wu H, Pangas SA, Eldin KW, et al. Juvenile granulosa cell tumor of the ovary: a clinicopathologic study. J Pediatr Adolesc Gynecol. 2017;30 (1):138-143.

43. Boussios S, Zarkavelis G, Seraj E, Zerdes I, Tatsi K, Pentheroudakis G. Non-epithelial ovarian cancer: elucidating uncommon gynaecological malignancies. Anticancer Res. 2016;36(10):5031-5042.

44. Ray-Coquard I, Morice P, Lorusso D, et al. Non-epithelial ovarian cancer: ESMO Clinical Practice Guidelines for diagnosis, treatment and follow-up. Ann Oncol. 2018;29(Suppl 4):iv1-iv18

45. Ghalleb M, Bouzaiene H, Sghaier S, et al. Fertility sparing surgery for ovarian sex cord stromal tumors: a nine case series. Pan Afr Med J. 2018;31:221

46. Lenck C, Chopin N, Gouy S, et al. The French national network dedicated to rare gynecological cancers diagnosis and management could improve the quality of surgery in daily practice of granulosa cell tumors. A TMRG and GINECO group Study. Gynecol Oncol. 2020;157(1):78-84.

47. Bryk S, Farkkila A, Butzow R, et al. Characteristics and outcome of recurrence in molecularly defined adult-type ovarian granulosa cell tumors. Gynecol Oncol. 2016;143(3):571-577.

48. Brown J, Sood AK, Deavers MT, Milojevic L, Gershenson DM. Patterns of metastasis in sex cord-stromal tumors of the ovary: can routine staging lymphadenectomy be omitted? Gynecol Oncol. 2009;113(1):86-90.

49. Rinne N, Farthing A, Borley J. Fertility sparing surgery in advanced and recurrent granulosa cell tumours of the ovary. J Obstet Gynaecol. 2018;38 (1):143-145.

50. Melero Cortes LM, Martinez Maestre MA, Vieites Perez-Quintela MB, Gambadauro P. Ovarian Sertoli-Leydig cell tumours: how typical is their typical presentation? J Obstet Gynaecol. 2017;37(5):655-659.

51. Iavazzo C, Gkegkes ID, Vrachnis N. Fertility sparing management and pregnancy in patients with granulosa cell tumour of the ovaries. $J$ Obstet Gynaecol. 2015;35(4):331-335.

52. Nasioudis D, Kanninen TT, Holcomb K, Sisti G, Witkin SS. Prevalence of lymph node metastasis and prognostic significance of lymphadenectomy in apparent early-stage malignant ovarian sex cord-stromal tumors. Gynecol Oncol. 2017;145(2):243-247.

53. Cheng H, Peng J, Yang Z, Zhang G. Prognostic significance of lymphadenectomyin malignant ovarian sex cord stromal tumor: a retrospective cohort study and meta-analysis. Gynecol Oncol. 2018;148(1):91-96.

54. Kuru O, Boyraz G, Uckan H, et al. Retroperitoneal nodal metastasis in primary adult type granulosa cell tumor of the ovary: can routine lymphadenectomy be omitted? Eur J Obstet Gynecol Reprod Biol. 2017;219:70-73.

55. Erkilinc S, Taylan E, Karatasli V, et al. Does lymphadenectomy effect postoperative surgical morbidity and survival in patients with adult granulosa cell tumor of ovary? J Obstet Gynaecol Res. 2019;45(5):1019-1025.

56. Ertas IE, Gungorduk K, Taskin S, et al. Prognostic predictors and spread patterns in adult ovarian granulosa cell tumors: a multicenter long-term follow-up study of 108 patients. Int J Clin Oncol. 2014;19(5):912-920.

57. Wang J, Li J, Chen R, Lu X. Contribution of lymph node staging method and prognostic factors in malignant ovarian sex cord-stromal tumors: a world wide database analysis. Eur J Surg Oncol. 2018;44(7):1054-1061.

58. Bergamini A, Ferrandina G, Candiani M, et al. Laparoscopic surgery in the treatment of stage I adult granulosa cells tumors of the ovary: results from the MITO-9 study. Eur J Surg Oncol. 2018;44(6):766-770.

59. Baekelandt J. Transvaginal natural orifice transluminal endoscopic surgery: a new approach to ovarian cystectomy. Fertil Steril. 2018 ; 109 (2):366.

60. Cui MH, Zhang XW, Zhao LP, Liu SY, Jia Y. Disseminated ovarian granulosa cell tumor after laparoscopic surgery: two case reports. Medicine. 2021;100(15):e25176.

61. Guillén G, Martín-Giménez MP, López-Fernández S, Molino JA, López M. Results of ovarian sparing surgery in pediatric patients: is there a place for laparoscopy? J Laparoendosc Adv Surg Tech A. 2020;30(4):458-463.

62. Tinelli R, Stomati M, Trojano G, et al. Laparoscopic treatment of ovarian granulosa cells tumor developed in the pelvic anterior preperitoneal space 20 years after laparotomic salpingo-oophorectomy: case report and review of literature. Gynecol Endocrinol. 2020;36(10):926-928.

63. Zapardiel I, Boria F, Halaska MJ, De Santiago J. Laparoscopic power morcellation: techniques to avoid tumoral spread. J Minim Invasive Gynecol. 2021;28(8):1442-1443.

64. Bercow A, Nitecki R, Brady PC, Rauh-Hain JA. Outcomes after fertility-sparing surgery for women with ovarian cancer: a systematic review of the literature. J Minim Invasive Gynecol. 2021;28(3):527-536.e521.

65. Yang B, Yu Y, Chen J, et al. Possibility of women treated with fertility-sparing surgery for non-epithelial ovarian tumors to safely and successfully become pregnant: a Chinese retrospective cohort study among 148 cases. Front Med. 2018;12(5):509-517.

66. Rees M, Angioli R, Coleman RL, et al. European Menopause and Andropause Society (EMAS) and International Gynecologic Cancer Society (IGCS) position statement on managing the menopause after gynecological cancer: focus on menopausal symptoms and osteoporosis. Maturitas. 2020;134:56-61.

67. Makhija A, Patel BM, Kenkre MA, et al. Retrospective analysis of 32 cases of ovarian granulosa cell tumours. J Obstet Gynaecol India. 2020;70 (1):50-56.

68. Ottolina J, Ferrandina G, Gadducci A, et al. Is the endometrial evaluation routinely required in patients with adult granulosa cell tumors of the ovary? Gynecol Oncol. 2015;136(2):230-234. 
69. van Meurs HS, Bleeker MC, van der Velden J, Overbeek LI, Kenter GG, Buist MR. The incidence of endometrial hyperplasia and cancer in 1031 patients with a granulosa cell tumor of the ovary: long-term follow-up in a population-based cohort study. Int J Gynecol Cancer. 2013;23 (8):1417-1422.

70. Nasioudis D, Orfanelli T, Frey MK, et al. Role of adjuvant chemotherapy in the management of non-granulosa cell ovarian sex cord-stromal tumors. J Gynecol Oncol. 2019;30(2):e19.

71. Wang D, Xiang Y, Wu M, et al. Is adjuvant chemotherapy beneficial for patients with FIGO stage IC adult granulosa cell tumor of the ovary? J Ovarian Res. 2018;11(1):25.

72. You D, Zhang Z, Cao M. Development and validation of a prognostic prediction model for postoperative ovarian sex cord-stromal tumor patients. Med Sci Monito. 2020;26:e925844.

73. Meisel JL, Hyman DM, Jotwani A, et al. The role of systemic chemotherapy in the management of granulosa cell tumors. Gynecol Oncol. $2015 ; 136$ (3):505-511.

74. Thakkar DN, Ramasamy K, Adithan S, Selvarajan S, Dubashi B. Frequency and risk factors of bleomycin-induced pulmonary toxicity in South Indian patients with germ-cell tumors. J Cancer Res Ther. 2021;17(2):443-449.

75. Karalok A, Ureyen I, Tasci T, et al. Maximum surgical effort is warranted for recurrent adult granulosa cell tumors of ovary. Tumori. 2016;102 (4):404-408.

76. Yasukawa M, Matsuo K, Matsuzaki S, Dainty LA, Sugarbaker PH. Management of recurrent granulosa cell tumor of the ovary: contemporary literature review and a proposal of hyperthermic intraperitoneal chemotherapy as novel therapeutic option. J Obstet Gynaecol Res. 2021;47 (1):44-51.

77. Benesch M, Lackner H, Pilhatsch A, Gurtl-Lackner B, Schwinger W, Urban C. Long-term remission in a female with multiple relapsed juvenile granulosa cell tumor. J Pediatr Hematol Oncol. 2015;37(8):e486-489.

78. Brown J, Brady WE, Schink J, et al. Efficacy and safety of bevacizumab in recurrent sex cord-stromal ovarian tumors: results of a Phase 2 trial of the Gynecologic Oncology Group. Cancer. 2014;120(3):344-351.

79. van Meurs HS, van der Velden J, Buist MR, van Driel WJ, Kenter GG, van Lonkhuijzen LR. Evaluation of response to hormone therapy in patients with measurable adult granulosa cell tumors of the ovary. Acta Obstet Gynecol Scand. 2015;94(11):1269-1275.

80. van Meurs HS, van Lonkhuijzen LR, Limpens J, van der Velden J, Buist MR. Hormone therapy in ovarian granulosa cell tumors: a systematic review. Gynecol Oncol. 2014;134(1):196-205.

81. Farkkila A, Haltia UM, Tapper J, McConechy MK, Huntsman DG, Heikinheimo M. Pathogenesis and treatment of adult-type granulosa cell tumor of the ovary. Ann Med. 2017;49(5):435-447.

82. Boussios S, Moschetta M, Zarkavelis G, Papadaki A, Kefas A, Tatsi K. Ovarian sex-cord stromal tumours and small cell tumours: pathological, genetic and management aspects. Crit Rev Oncol Hematol. 2017;120:43-51.

83. Zhang N, Chen R, Hua K, Zhang Y. A retrospective study of reproductive outcomes after fertility-sparing surgery and postoperative adjuvant chemotherapy in malignant ovarian germ cell tumors and sex cord-stromal tumors. J Ovarian Res. $2017 ; 10(1): 52$.

84. Jamieson S, Fuller PJ. Tyrosine kinase inhibitors as potential therapeutic agents in the treatment of granulosa cell tumors of the ovary. Int J Gynecol Cancer. 2015;25(7):1224-1231.

85. Dridi M, Chraiet N, Batti R, et al. Granulosa cell tumor of the ovary: a retrospective study of 31 cases and a review of the literature. Int $J$ Surg Oncol. 2018;2018:4547892.

86. Shu S, Deng S, Tian JQ, et al. The clinical features and reproductive prognosis of ovarian neoplasms with hyperandrogenemia: a retrospective analysis of 33 cases. Gynecol Endocrinol. 2019;35(9):825-828.

87. Colombo N, Peiretti M, Garbi A, Carinelli S, Marini C, Sessa C. Non-epithelial ovarian cancer: ESMO Clinical Practice Guidelines for diagnosis, treatment and follow-up. Ann Oncol. 2012;23(Suppl 7):vii20-26.

\section{Publish your work in this journal}

Cancer Management and Research is an international, peer-reviewed open access journal focusing on cancer research and the optimal use of preventative and integrated treatment interventions to achieve improved outcomes, enhanced survival and quality of life for the cancer patient. The manuscript management system is completely online and includes a very quick and fair peer-review system, which is all easy to use. Visit http://www.dovepress.com/testimonials.php to read real quotes from published authors.

Submit your manuscript here: https://www.dovepress.com/cancer-management-and-research-journal 